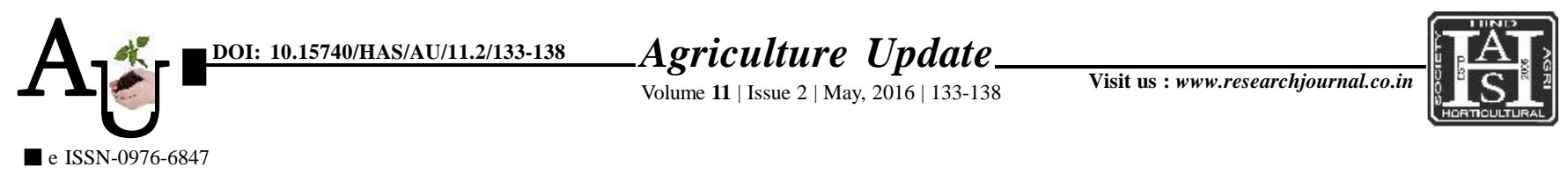

\title{
Research Article: Association of personal, social and economic attributes of farmers on demonstrated groundnut production technology
}

M.V. POKAR, R.M. JAVIA AND B.C. BOCHALIYA

Article Chronicle:

Received :

19.02.2016;

Revised :

12.03.2016;

Accepted :

13.04.2016

KeY Words:

Groundnut

production

technology,

Front line

demonstration,

Socio-economic

analysis
SUMMARY : The present study was conducted in 4 villages of Banaskantha district of Gujarat to know personal, social and economic characteristics of the beneficiary and non-beneficiary farmers of demonstrated groundnut production technology. Results revealed that maximum number of the respondents from beneficiary and non-beneficiary groups were middle aged (47.14\% and $51.43 \%)$ and having primary education $(37.14 \%$ and $47.14 \%)$. Majority respondents from beneficiary and nonbeneficiary farmers were medium size of family $(65.71 \%$ and $71.43 \%)$ and social participation with membership in one organization $(48.57 \%$ and $55.71 \%)$. There was non-significant difference between beneficiary and non-beneficiary farmers with respect to their age, education and size of family. Maximum number of respondents from beneficiary and non-beneficiary groups had semi-medium farm size $(44.29 \%$ and $48.57 \%$ ), medium annual income $(80.00 \%$ and $82.86 \%$ ) and had medium market orientation $(70.00 \%$ and $60.00 \%$ ). Social participation, size of farm, annual income and market orientation were found to be significant indicating there was significant difference between beneficiary and non-beneficiary farmers.

How to cite this article : Pokar, M.V., Javia, R.M. and Bochaliya, B.C. (2016). Association of personal, social and economic attributes of farmers on demonstrated groundnut production technology. Agric. Update, 11(2): 133-138 (DOI : 10.15740/HAS/AU/11.2/133-138).

\section{R.M. JAVIA}

Krishi Vigyan Kendra

(J.A.U.), Nana-

kandhasar (Chotila),

SURENDRANAGAR

(GUJARAT) INDIA

Email: rmjavia@

gmail.com

See end of the article for

authors' affiliations 